\title{
Osmanlı’dan Günümüze Din-Devlet ve Laiklik Tartışmaları
}

\section{Gül Tuba Dağcı' ${ }^{1}$, Adnan Dal ${ }^{2}$}

\section{Özet}

Bu çalışmada laikliğe yönelik tarihsel bir perspektifle felsefi, sosyolojik ve siyasi açllımlar getirilmeye çalışılmış; kavram öncelikle Batı'nın bir ürünü olarak kavramsal ve kronolojik bir çerçevede ele alındıktan sonra onun Osmanlı'da nasıl zemin bulduğu ifade edilmeye çalışılmıştır. Son olarak cumhuriyet dönemiyle birlikte laikliğin toplumumuzda din-devlet çatışmasında nasıl bir yer tuttuğuna değinilmiştir. Klasik tabiriyle toplumumuzdaki "din işlerinin devlet işlerinden ayrı tutulması" tanımına Batı'da rastlanmadı̆̆̆, bu açıdan genel olarak yerel bir tanımlama olarak görülen laiklik, gelecekte de kamuoyunun gündemini oluşturan ana tartışmalardan biri olacak gibi görünmektedir.

\begin{abstract}
In this study, it's tried to explain philosophical, sociological and political initiatives of laicism through historical perspective, then, as a material of Western countries it is primarily expressed conceptually and chronologically before declaring it how was effective during Ottoman Empire. Finally, we planned to clarify the place of laicism between religion-state political dilemma. Beyond the clasical concept of laicism in Turkey as "religion and state is fonctually separated", in western countries this expression is invalid, unlike Turkey has a local definiton of laicism. This aspect of laicism will be potantially a main conflict of public agenda in the future.
\end{abstract}

Anahtar Kelimeler: Laiklik, Sekülerizm, Roma, Osmanlı

\footnotetext{
${ }^{1}$ Yalova Üniversitesi Öğretim Üyesi.

${ }^{2}$ Fırat Üniversitesi Araştırma Görevlisi.
} 


\section{Gül Tuba Dağcı, Adnan Dal}

\section{Giriş}

İnsanlar içinde bulundukları toplumun kültür kalıplarına dayanan kendine özgü yaşam koşulları içinde var olurlar. Bu nedenle genel bir ifadeyle, kişilik kültür yapısının bireysel bir ifadesi, kültür ise kişiliğin kolektif ifadesidir denilebilir. "Din”, kültürün bir parçası ve temel bir toplumsal kurum olarak toplumsal yapının önemli bir unsurudur. Bu nedenle insanlar içine doğdukları toplumsal grupta belirli bir dinin değer ve inançlarıyla direkt olarak muhatap olurlar. Örgütlü ya da örgütlenmemiş din, tarihsel süreçte gücü ve etkinliği değişmiş olsa da toplumsal yapıyı oluşturan ekonomi, siyaset, hukuk, ahlak, kültür vb. alanlarla sürekli bir karşılıklı ilişki içinde bulunmuştur. $\mathrm{Bu}$ nedenle din; gerek bireysel olarak, gerekse kolektif olarak tanımlanan "kimlik"lerin oluşturulmasında etkili olmuştur.

Batı'nın kilise-devlet çatışmasının bir ürünü olan laiklik olgusu ise, günümüz Türkiyesi'nin güncel tartışmalarından birini oluşturmaktadır. Türkiye'de cumhuriyetin ilanıyla beraber yoğun bir ivme kazanan batılılaşma projesinin önemli bir ayağını oluşturan laiklik, zaman zaman toplumun algısal ayrılıklarına neden olabilmektedir. Genelde din temelli bir argümanla muhalefete maruz kalan laiklik, Batı'da bu tür tartışmaları geride bırakmasına rağmen ülkemizde hala tartışma zemini bulabilmekte, bu amaçla detaylı araştırmalara konu olabilmektedir. Araştırmadaki temel amacımız, laikliğe nesnel ve geçerli bir temellendirme kapsamında atıf yaptıktan sonra, kendi gerçekliğimizde Osmanlı'dan günümüze bu kavramın ne tür tartışmalara maruz kaldığını açıklamaya çalışmaktır. Araştırmayı laikliğin kronolojik bir analiziyle detaylandırmaya çalıştıktan sonra konuya sonuç mahiyetinde bir takım öneriler sunmaya gayret edeceğiz. 


\section{Osmanlı’dan Günümüze Din-Devlet ve Laiklik Tartışmaları}

\section{TARIHHSEL SÜREÇ ICCERISINDE DİN-DEVLET-LAIKLIK İLISSKISI}

Osmanlı ve Türkiye'deki din-devlet-laiklik ilişkisini anlayabilmek için öncelikle Batı dünyasındaki laiklik kavramının etimolojisini, din-devlet ilişkisi bağlamında laiklik sürecini incelemek; konuyu daha iyi kavramamıza imkân sağlanacağını düşünüyoruz.

\section{a) Laiklik Kavramının Etimolojisi:}

Etimolojik açıdan Latincedeki "Laicus" sözünden gelen laiklik terimi Türkçeye Fransızcadaki "laic/laique" sıfatından geçmiştir. Batı dillerinde "dine ya da kiliseye ait olmayan” anlamına gelir. Daha eskiye gidersek, Eski Yunanlılar "laikos" terimiyle, "halktan olan” kişiyi ifade etmektedir. Ortaçağ Latincesinde bu kelime "laicus" biçimini alarak, "ruhban olmayan/kiliseye mensup olmayan/herhangi bir dinsel işlevi ve unvanı olmayan” kişi anlamlarında kullanılmıştır. "Laicus" terimi metinlerde 13. yy.den beri görülmeye başlanmış ve kavramsal içeriği bu tarihten sonra doldurulmuştur. ${ }^{3}$

Laikliğin tek bir anlayış biçimi yoktur. Kavramın, geniş bir perspektiften hareketle üç alanda ele alınması mümkündür. Laikliği, Anglo-sakson dünyasındaki “sekülerizm” kavramı ile birlikte düşündüğümüzde felsefi, sosyolojik ve siyasi-hukuki anlamları açısından ayrı ayrı ele alabiliriz. Felsefi bakımdan laiklik, metafizik ve teolojik inanış ve varsayımları rasyonel bilgiden ayırarak, bilginin referansının Tanrısal

üstün görülmesiyle ilgilidir. Batı dünyasında Ortaçağ’’n sonlarında başlayıp modernitenin temel uğrak noktaları olarak kabul edilen Rönesans, Reform ve Aydınlanma dönemi boyunca çeşitli düşünürlerin/filozofların katkılarıyla güçlü bir gelenek haline gelen laik-rasyonel düşünce, eski Tanrısal evren anlayışı yerine modern bilimlerin de temelinde yer alan rasyonel bir evren tasarımı geliştirmiştir. $\mathrm{Bu}$ anlamıyla sınırlı düşünürsek laikliğin önceki dinsel evren tasarımıyla çatıştığını, ona karşıt olduğunu söyleyebiliriz. Felsefi anlamını diğer anlamlarından ayrıştırmak için, laik düşünce akımlarını ve bunlara bağlı hareket ve tutumları ifade etmede laiklik yerine Fransızca'daki anlamına yakın olarak "laisizm” (laicisme) kavramını kullanabiliriz. ${ }^{4}$

Sosyolojik anlamda laikliği ifade etmek için özellikle "sekülerleşme” terimi kullanılmaktadır. Bu terim esasen, Anglo-sakson dünyada, laiklik kelimesinin farklı içerikte karşılığıdır. Bu bağlamda laikliğin sosyolojik anlamı, dinin toplumsal hayattaki etkisinin en aza indirilmesini, toplumun büyük ölçüde "sekülerleşmesini”" (dünyevileşmesini) ifade eder. Bu durum toplumsal yapı ve ilişsilerde insan aklı ve yaşama pratiğinin temel olması, dini mistik ve irrasyonel unsurların ikinci plana düşmesi demektir. Bir başka ifadeyle, modernleşme ile birlikte yaşanan sekülerleşme sürecinde dinin toplumsal önemi azalmakta; din, toplumsal rol ve kurumların işleyişinde ve bireysel inanç ve eylemlerde daha az etkili olmaktadır. ${ }^{5}$

Siyasi-hukuki anlamda laiklik konusuna gelince, bu alanda kavramsallaşma sürecinin Batı'da ortaya çıkan kilisedevlet çatışmasının devlet lehine sonuçlanmasıyla başladığını görmekteyiz. Batı'nın düşünce geleneğinin bir çıktısı olan siyasi-hukuki anlamda laikliğin pratikteki örneklerine makalemizde Bizans, Osmanlı, Türkiye örnekleriyle yer vermeye çalışalım.

\footnotetext{
${ }^{3}$ ACAR, Sadık (bty), "Laiklik Konusunda Kavram Karmaşası", ss1-4

${ }^{4}$ TÜRKÖNE, Mümtaz'er (2006), Siyaset, Lotus Yayınlar1, 4.Bask1, Ankara,s.534.

5 ÖKTEM, Niyazi (1994), “Dinler ve Laiklik”, Cogito, Sayı:1, Yaz, ss. 31-47.
} 


\section{Gül Tuba Dağcı, Adnan Dal}

\section{b) Laikliğin Gelişim Süreci}

Siyasal-dinsel alan ilişkisi tarihsel süreçte farklı şekiller almıştır. Batı dünyasında "iktidarın ilkesi/özü” (auctorias) ile "iktidarın uygulanması/kullanılması" (potetas) tek bir merkezde toplayan demokratik meşruiyetle donanmış modern devletin görünür olmasına dek din-devlet ilişkisi, kilise-devlet çatışması biçiminde çeşitli şekiller alarak devam etmiştir. Siyasal toplumun örgütlenmesinde Batı düşünce ve uygarlığının ürünü olan siyasi-hukuki bir ilke olarak laiklik, Avrupa tarihinde yaşanan kilise-devlet mücadelesinin/çatışmasının bir ürünüdür. ${ }^{6}$

Başlangıçta siyasal iktidar sorunuyla doğrudan ilgisi gözükmeyen Hıristiyanlık, zamanla kilisenin hiyerarşik bir örgütlenme haline gelmesiyle birlikte, kendi devlet ve toplum felsefesini oluşturmuştur. Süreç içinde M.S. 305 'te (çeşitli sebepler zinciri çerçevesinde) imparator olan Konstantinus'un Hıristiyan olması ile beraber bu din taraftarları özgürlük kazanmış ve imparator I.Theodosius tarafından bu din "devletin resmi dini”" haline getirilmiştir. Roma İmparatorluğu'nun resmi dinsel inanç sistemi haline gelen Hıristiyanlık, kilise çerçevesinde hiyerarşik biçiminde örgütlenmiş bir devlet kurumu niteliği kazanmıştır. Batı Roma’nın zayıflaması ve çöküşüyle Batı dünyasında merkezi ve güçlü bir iktidarın olmayışının yarattığı boşluk, kilise ile dünyevi-siyasal iktidar arasındaki ilişkilerin kilisenin üstünlüğü yönündeki tezleri doğurmuştur.

Ortaçağın sonlarına doğru ( siyasal alan ile kilise alanının iktidar gücünün elinde tutmak için karşılıklı çatışması sonucu) siyasal iktidarın laikleşme süreci hızlandı. Dönemin en önemli düşünürleri dünyevi iktidarın bağımsızlı̆̆ını meşrulaştıran öğretiler geliştirdiler. Bu noktada kiliseyi siyasal iktidarın boyunduruğu altına sokup, siyasetin özerkliğini ve bunun uzantısı olan devletin "birliğgi”ni kuramlaştırarak modern anlamda devlet kavramının düşünülebilmesine ve sistemleşebilmesine katkı yapan ilk düşünür Marsilius’tur. ${ }^{7}$ Ona göre, papanın dini iktidarı da, dünyevi iktidarı da meşru değildir, bir gasptır. Kilisenin ya da papanın otoritesinden söz etmek, zorlayıcı yargı gücüne sahip olmadıkları için anlamsızdır. Devlet içinde devlet olamayacağı için kilise sivil yasaya ve bu yasayı uygulayan prenslere boyun eğmek zorundadır. Otorite yalnızca devlette bulunur. Ruhanidünyevi ayrımı gereksizdir; çünkü tek bir toplum ve tek bir iktidar vardır; onlar da dünyevidir. Özetle bu düşüncenin ulaştığı sonuç; din işleri ile kiliseyi tümüyle devletin boyunduruğu altına sokan bir laiklik (ya da dünyevileşme) anlayışıdır.

16.yy.den itibaren Fransa'dan İngiltere'ye, Almanya'dan İsviçre'ye, Avrupa'nın batısı ile doğusunda yaygınlaşan "Reform Hareketi”, devlet iktidarını Roma kilisesinin etkisinden kurtararak daha da güçlendirmiştir. (Bu reformun öncüleri; Luther, Calvin, Zwingli'dir.) Reform bu yönüyle Roma kilisesini ve bu kilisenin hiyerarşik örgütlenişini parçalamıştır. Laiklilik açısından baktığımızda; reformun sonucu, siyasal iktidarı elinde tutan "prens" ile ulusal nitelikteki yeni kilise örgütlenmelerinin birleşmesi, dünya üzerinden iktidarın tekelleşmesi olmuştur. Reform ile birlikte yaşanan kilise ile devlet ayrılması anlamında bir laiklik değil; dinsel olanın (kilise) dünyevi olana (devlet) bağımlı olması anlamında bir dünyevileşmedir.

\footnotetext{
${ }^{6}$ TÜRKÖNE, Mümtaz'er (2006), Siyaset, Lotus Yayınlar1, 4.Bask1, Ankara,s.527.

${ }^{7}$ TÜRKÖNE, Mümtaz'er (2006), Siyaset, Lotus Yayınları, 4.Baskı, Ankara,s.529.
} 


\section{Osmanlı’dan Günümüze Din-Devlet ve Laiklik Tartışmaları}

Bu gelişmeler sonucunda laik modern devlet Avrupa'da 16-17. yy.de somutlaşmıştır. Buna göre kurumsallaşmış siyasal iktidar, meşru olabilmek için artık dışsal ya da aşkın bir güce ihtiyaç duymaz. Devlet meşruluğunu kendisinden alır, daha doğru ifadeyle devlet direkt olarak meşru bir zemindir.

Devletin dinsel meşruluğu, toplum sözleşmesi kuramlarına dek sürmüştür. Toplum sözleşmesi düşüncesinin gelişmesi ve doğal hukukun laikleşmesiyle birlikte egemen güç Tanrı yerine bireylere/topluma/yönetilenlere dayandırılmaya başlanmış, yani egemenlik demokratik bir meşrulukla donatılmıştır.

Görüldüğü üzere batı dünyasında laiklik; kilise ile dünyevi-siyasi otoriteler arasındaki mücadelenin, bir başka deyişle Hıristiyan dini geleneğinin tarihsel pratiğinin sonucudur. Laiklik, bir öğreti olarak Hıristiyan dininin, dini-siyasi alan ayrımı yapmasından çok, tarihsel süreçteki örgütlenmesinin ve iktidar mücadelesinin sonucudur. Hıristiyan dünya görüşünün hâkimiyeti altındaki dünyevi iktidar odakları da kilise karşısındaki mücadelelerinde dinsel tezler kullanılmıştır. Dolayısıyla sorun, bir doktrin sorunundan çok pratikte kilise-devlet çatışmasıdır. Bu nedenle laiklik bağlamında Hıristiyanlık ve İslamiyet arasındaki farklılık temelinden hareketle yapılan yorumlara da eleştirel yaklaşmak gerekir. Bu yorumlara göre, İslam'dan farklı bir özellik olarak Hıristiyanlığa atfedilen din-devlet ayrımı ilkesi, Hz. İsa'nın meşhur “Sezar'ın hakkını Sezar’a verin” hükmüne dayandırılmaktadır. Ancak bu yorum İncil'deki “Hiç kimse iki efendiye kulluk edemez” vb. gibi tam ters yöndeki birçok hükmün ihlal edilmesine dayalı eksik bir yorumdur. Çünkü iki din de teosantrik (Tanrı merkezli) birer öğreti oldukları için, dini alan ile dünyevi alan arasında ayrım yapmaz. Ancak her iki dinin tarihsel pratikleri toplumsal ve siyasal örgütlenme açısından farklı olmuştur. Hıristiyanlıkta bağımsız bir örgütlenmeye sahip olan din adamları sınıfının (Kilise) İslam’da karşılı̆̆ı yoktur.

Hıristiyanlık, Bizans örneği dışında, siyasal iktidarının dağınık olduğu toplumlarda kurumlaşırken; İslamiyet, çoğunlukla merkezi otoritenin güçlü olduğu toplumsal örgütlenmeler içinde kurumlaşmıştır. Bu nedenle, Hıristiyanlık Ortaçağ boyunca görece bir siyasi otonomi sahibi olmuş, buna karşılık İslam her zaman merkeziyetçi bir devletle iç içe olmuştur. ${ }^{8}$ Bir başka ifadeyle Müslüman toplumlarda dinsel liderlik Batı'da olduğu gibi ayrı bir kilise biçiminde örgütlenmemiş, büyük ölçüde yöneticilere bağımlı kalmıştır. Dolayısıyla bu geleneğin ortaya çıkardığı din-devlet ilişkisi modeli hiçbir zaman "din devleti” modeli değildir; "devlet dini”" modelidir. İslam geleneği bu alanda Hıristiyan Ortodoks geleneğinden farklıdır.

Kısacası laiklikle ilgili değerlendirmeleri dinlerin dogmalarıyla, tarihsel-siyasal geleneklerini karıştırmamak gerekir; çünkü her dinin, doğuşundan sonra kurumsallaşma süreci boyunca, birbirinden farklı "din-devlet ilişkisi” modelleri ortaya çıkmaktadır. Bu bağlamda diyebiliriz ki; laiklik de gerek din-devlet ilişkilerinin bir sonucu gerekse toplumların din-devlet algısındaki zihinsel oluşum evrelerine ve kendi özgün dinamiklerine göre farklı toplumlarda farklı şekillerde meydana gelmiştir.

\section{OSMANLI İMPARATORLUĞU DÖNEMİNDE LAİKLİK}

\section{Osmanlı'da Din-Devlet İlişkisi}

\footnotetext{
${ }^{8}$ MERT, Nuray (1994), “Laiklik Tartışması ve Siyasal İslam”, Cogito, Sayı:1, Yaz, ss. 87-89
} 


\section{Gül Tuba Dağcı, Adnan Dal}

Türkiye'de laikliğin siyasi ve hukuki anlamda kurumsallaşması esas itibariyle Cumhuriyet döneminde gerçekleşmiş olmakla birlikte Osmanlı Devleti’nden alınan miras da belli açılardan etkili olmuştur. Öncelikle belirtmek gerekir ki, Osmanlı Devleti yaygın kanaatin aksine teokratik bir yapı ve işleyişe sahip değildir. Resmi bir devlet dininin bulunmasıyla o devletin teokratik oluşunu birbirine karıştırmamak gerekir. Kanun-i Esasi’de yer alan “devlet-i Osmaniye’nin dini, din-i Íslam'dır “ denmesi, 1924 Anayasası'nda geçen “devletin dini Íslam'dır" denmesinde olduğu gibi, hükümler ilgili devletin teokratik bir sisteme sahip olduğunu göstermez. Osmanlı'da siyasi iktidarın meşruluk temeli büyük ölçüde dinsel olmakla beraber, hukuk düzeni tümüyle dini değildir ve siyasi sürecin işleyişinde din-dışı unsurlar de-facto (kendiliğinden) etkili olmuştur.

Osmanlı yönetim geleneğinde devletin merkezi konumu ve din karşısındaki önceliği, dini oluşumların devletin denetimi dışına çıkmasına izin vermemiş ve gerektiğinde bunu sağlamak için sert yaptırımlara neden olmuştur. Osmanlı'da devlet-din ilişkisi “devletin her hal ve şartta dinin önde olması” şeklinde tanımlanabilir. Devlet gerekleri dini gereklerin önünde yer alırken, ikisi arasında olası bir çatışmada, devlet tartışma dışı tutulur; dini gerekler devlet gereklerine göre yorumlanır. Bir başka deyişle, teokrasi ilkelerinin tersine Osmanlı düzeninde, “devlet maslahatı" din maslahatından üstün tutulmuş, dinsel olmayan hukuk ve toplumsal ilişkiler "devlet maslahatı" gereği varlığını sürdürmüştür. Buna bir örnek verecek olursak; Fatih Kanunnamesi'nde yer alan kardeş katli yasası, dinin ve geleneğin dışında sadece "devlet aklı"nın buyruğu ile açıklanabilir. 9

Osmanlı'da öncelikli olan devlet gerekleridir, din tamamıla devletin otoritesinin emrinde bir kurumdur. Cumhuriyet Türkiye'sinde devletin dini kendi emrinde bir kuruma dönüştürme projesi, devleti “ulema"nın ve tarikat önderlerinin etkisinden korumaya dönük çabası Osmanlı'dan tevarüs eden geleneğin göstergesidir.

Osmanlı Devleti'nde laiklik, Batı'dan gelen kültürel etkilenmelerle, modern kurumların ancak laik bir yaklaşımla geliştirilebileceği inancıyla değil, doğrudan doğruya boyun eğilen siyasi zaruretlerin gereği olarak ortaya çıkmıştır. Bu nedenle Cumhuriyet'e gelene kadar girişilen laik uygulamaları siyasi laiklik olarak nitelendirilebilir. Avrupa devletlerinin Hıristiyanlar lehine müdahalelerini önlemek ve etkin unsurların ayrılıkçı eğilimlerini frenlemek için eşitlikçi politikalar uygulamak zorunda kalan Osmanlı, fertlerin dini inançları yüzünden farklı muameleye tabi tutulmaları, hukuk önünde herkesin eşit olması anlamında laikliğin önemli bir aşaması olan "müsavat" prensibini kabul etmiştir. 1856 yılında ilan edilen Islahat Fermanı tam anlamıyla laik bir metindir.

Türk toplumunda 19. yy. boyunca, siyasi alanın dışında laikliğin yerleşebileceği felsefi-kültürel temeller, hemen hemen hiç yoktur. Ancak bu dönemdeki siyasi laiklik; devleti, kağıt üzerinde laikleştirmeye başlamıştır. Siyasal alanda yapılan bu düzenlemeler, Cumhuriyet'e kadar devam eden ikiliklerin bir cephesini oluşturur. Tek taraflı laik düzenlemelerin toplumda bir karşılığının bulunmaması, kendi felsefesini geliştirememesi, bunun siyasi laiklikle sınırlı kalmasına yol açmıştır. Ancak, bu sınırlılıklara rağmen Cumhuriyet aydınları laiklik prensibini devletin anayasal temeline yerleştirebilmişlerdir. Türk İslami’nin esnek İslami yorumlar üretme geleneği, ulemanın asırlar boyu devletin bir uzvu ve tamamlayıcısı olması, Sünni İslam’ın aktivist bir muhalefet

\footnotetext{
${ }^{9}$ GENCER, Bedri (2000), “Türkiye'de Laikliğin Tarihi Dinamikleri”, Toplum ve Bilim, Say1: 84, Bahar, ss 151-171.
} 


\section{Osmanlı’dan Günümüze Din-Devlet ve Laiklik Tartışmaları}

geleneğinin bulunmaması ve Osmanlı döneminde yaşanan siyasi laiklik bunu mümkün kılan unsurlar arasında zikredilebilir.

\section{CUMHURIYYET DÖNEMİNDE LAİKLİK}

\section{Hukuksal Çerçeve}

Türkiye Cumhuriyeti (T.C.), laik devlet ilkesini anayasasının temel prensiplerinden birisi olarak kabul etmiş ve çeşitli hükümlerle güvence altına almaya çalışmıştır. Bu ilke Anayasanın 2. maddesinde "devletin nitelikleri”" arasında yer almakla beraber, aynı zamanda pek çok başka anayasa hükmünün de konusunu oluşturmaktadır. Bu nedenle laiklik, siyasal rejimin niteliği açısından temel atıf noktalarından birini oluşturmaktadır. Bizzat anayasanın lafzına göre, laiklik veya "laik Cumhuriyet", Türkiye’nin sosyo-politik sisteminin en önemli unsurudur.

Hukuksal çerçevede, temelleri daha eskiye uzanmakla beraber, laiklik bir ilke olarak anayasalarımıza 1924 Anayasasında 1937 yılında yapılan değişiklikle girmiştir. Laikliğin hukuksal açıdan kurumsallaştırılması için atılan adımlar arasında, en önemlileri olarak, hilafetin kaldırılması ve eğitimin birleştirilmesine (Tevhid-i Tedrisat Kanunu) ilişkin kanunlar (1924) tekke ve zaviyelerin kapatılması (1925), Medenin kanunun kabulü (1926), 1924 Anayasasının 2. Maddesinde yer alan “Türkiye Devleti’nin dini İslam’dır.” ibaresinin anayasadan çıkartılması (1928) sayılabilir. 1928'den bu yana Türk anayasalarında devlet dini ile ilgili bir hüküm bulunmamaktadır.

\section{Din-Devlet-Laiklik Algısı}

Cumhuriyet dönemi özellikle tek partili dönem sonrası en çok tartışılan sorun alanlarından birisi din-siyaset ilişkisi ve bu bağlamda laiklik konusu olmuştur. Farklı kesimler, çeşitli kişi ve gruplar bu kavramlardan farklı şeyleri anlamakta, laikliği farklı tanımlamaktadırlar. "Dini siyasete alet” ederek laikliğin ortadan kaldırılmaya çalışıldığı iddiası, demokratik siyasal süreci kesintiye uğratan otoriter müdahalelerin laikliği korumak adına yapılması temel hukuki metinlerdeki birçok hükmün devletin temel niteliklerinden birisi olan laikliğe atıfla açıklanması vb. gibi noktalar hep laiklik kavramının anlamı veya anlamlandırılması çerçevesinde anlaşılabilir. Laiklik kavramı Türkiye'deki siyasi kutuplaşmanın etrafında şekillendiği temel kilit kavramlardan birisidir. Ancak siyasi tutumların bu kavrama göre belirlenmesi, saflaşmanın bu kavrama göre gerçekleşmesi, siyasi mücadelenin ve altında yatan sosyal gerçekliğin doğal halinin gözden kaçmasına, üzerinin örtülmesine yol açmaktadır.

Cumhuriyetin din olgusuna bakışı ve bu alandaki düzenlemeleri genel bir ifadeyle, dini devlet kontrolü altına almak ve mümkün olduğunca dar bir alanda tutmaktır. Bunun için de Müslüman halkın dini ihtiyaçlarının karşılanması bir kamu hizmeti olarak görülmüş ve Diyanet İşleri Başkanlığı bu hizmeti yerine getirmek için kurulmuştur. Böylece Cumhuriyet kurucuları, İslam'ın, devleti ve siyasal iktidarı etkilemesini ve dinin tamamen özerk, devletten bağımsız olarak gelişebilen bir alan olmasını önlemek istemişlerdir. ${ }^{10}$ Dinin tarikatlar ve cemaatler eksenindeki varoluşuna savaş açılması, aklileştirilerek devlet denetimine alınması, bu dinsel unsurların

\footnotetext{
${ }^{10}$ TÜRKÖNE, Mümtaz'er (2006), Siyaset, Lotus Yayınları, 4.Bask1, Ankara,s.533.
} 


\section{Gül Tuba Dağcı, Adnan Dal}

batıyı yakalamak için girişilen hızlandırılmış modernleşme çabaları önünde bir engel olarak görülmesinden kaynaklanmaktadır.

Batı'da laiklik, din adamları sınıfının toplum üzerindeki yetkilerinin sınırlaması ve dinin vicdani yönünün öne çıkarılmasıyla gelişmiştir. Oysa İslam toplumlarında böyle bir yapılanma olmadığından, kanuni bir düzenleme ile dini bir vicdan işi haline getirmek mümkün değildir. Cumhuriyet'in tekke, zaviye ve medreseleri kapatması, tek başına dini normların toplum içindeki yaygınlığını önlemeye yetmemiştir. Bu nedenle başvurulan yol, dini devlet tekeline alarak kontrol altında tutmak olmuştur. Devletin dini kendi kontrolüne alması, Osmanlı'dakine benzer bir "resmi İslam" görünüşü oluştururken, devlet dinin laikleştirilmesine teşebbüs etmiştir.

Cumhuriyet'in toplum projesi rasyonalist ve bütüncü bir projedir. Bir çeşit modernleşme projesi olan bu proje, devletin sahip olduğu bütün aygıtları kullanarak, sadece dini anlamda değil; aynı zamanda kültür, dil, sanat ve tarih gibi alanlarda köklü bir dönüşümü gerçekleştirme amacına yöneliktir. Tek parti laiklik uygulamalarının köktenciliğii, Cumhuriyet'in bu bütüncü toplum projesi göz ardı edilerek anlaşılamaz. Kökenlerini Osmanlı'nın son dönemlerinden alan sekülerleşme süreci, ülkemizde de Fransa'da olduğu gibi Cumhuriyet'in kuruluşuyla birlikte devrimci ve köktenci yollardan ivme kazandığı için bu dönem laiklik yorum ve uygulamalarını bir çeşit "laik toplumsallaştırma süreci" olan "laisizm" kavramı ile ifade edebiliriz. ${ }^{11}$ Kısacası din, bireylerin özel alanlarında bir özgürlük konusudur, özel alan dışında resmi ve hiyerarşik bir örgütlenmeye konu olacak şekilde denetim altındadır; dolayısıyla bireyler dinlerini ancak devletin tanımladığı şekilde öğrenebilirler. Bu dönemdeki laisizme dönüşen laiklik uygulaması, devlet eliyle Batı uygarlığını yakalamaya ve bunun için de bütüncü bir kültür devrimini gerçekleştirmeye yönelen yeni siyasal rejimin, dini oluşumları bu hedefinin önünde engel olarak görmesi ve laiklik politikalarını "irticayı önlemek", "gericiliği önlemek" için zorunlu uygulamalar olarak düşünmesinden kaynaklanmıştır.

Laisizm, Cumhuriyet'in eski geleneği yıkmak ve kendi geleneğini oluşturmak için başvurduğu en stratejik araç olmuştur. Güneş dil teorisi, Türk tarih tezi, Latin alfabesinin kabulü gibi yenilikleri de bu cümleden sayabiliriz. Cumhuriyet'in resmen benimsediği Pozitivizm de bu yeniliğe uygun bir ideolojik temel olarak kabul edilmiştir. Aynı dönemde din, merkeze karşı zayıf bulunan taşranın kendini ifade ve varlığını devam ettirme kanalı haline gelmiştir. Türk toplumunda din-devlet uzlaşması temeline dayalı siyasi gelenek çok güçlüdür. Bu nedenle dini tepkiler, hukuki bir ilke olarak laikliğe değil, laisizmin bir ideoloji olarak Sünni İslam'ın karşısına rakip olarak çıkartılmasına yöneltilmiştir ve bu durum, laikliğin din düşmanı olarak algılanmasına ve Müslümanların dini faaliyetlerinin artan oranda siyasileşmesine neden olmuştur. Kısacası, tarihsel uzlaşmanın 1ş̧ı̆ında dini, bireysel bir alan olarak gören ve yaşayan Müslümanlar, laisizmin meydan okumaları ile karşılaşınca, dine toplumsal bir ifade aracı olarak müracaat etmeye başlamışlardır. 1950'li yılarak kadar elit kesimin elinde "toplumu değiştirme" idealinin en güçlü ideolojik silahı olan laikliğe karşı direnen toplumsal kendi muhalefetlerini, çok partili demokratik hayata geçişle birlikte siyaset katına ulaştırmaya başlamıştır. Günümüze kadar da din ve laiklik en güçlü siyasal bölünme faktörlerinden ve siyasetin merkezi konumlarından birini oluşturmuştur.

\footnotetext{
${ }^{11}$ TÜRKÖNE, Mümtaz'er (2006), Siyaset, Lotus Yayınları, 4.Bask1, Ankara,s.554.
} 


\section{Osmanlı’dan Günümüze Din-Devlet ve Laiklik Tartışmaları}

\section{Sonuç}

Toplumsal yapının iki önemli unsuru olan din ve devlet, diğer toplumsal yapı unsurları gibi kaçınılmaz olarak karşılıklı ilişki içindedirler. İlişskinin niteliği ve kurumsallaşması tarihsel süreçte, farklı dinsel geleneklerde ve kültürel iklimlerde değişik modeller oluşturacak tarzda bir gelişim göstermiştir. Laiklik, laisizm, laikçilik, Fransız modeli laiklik, sekülerizm, vb. gibi kavramlar bu tarihsel farklılık ve özgüllüğün neticesidir.

Günümüz Türkiyesi’nde uygulanan laiklik modelinin kökeni 19. yy. Osmanlı dönemi yenileşmesine kadar uzanmaktadır. Temelini Osmanlı'dan alan ve Fransız modeli laikliği ${ }^{12}$ benimseyen Türkiye Cumhuriyeti, laik sistemi genişletilerek uygulanmış ve devletin anayasasına koyarak Cumhuriyet Türkiyesi'nin din-devlet ilişkisini resmi olarak oluşturmuştur. Şunu da eklemekte fayda vardır; her toplumun kültürel ve coğrafi kodları farklıdır. Bu minvalde, Türkiye Cumhuriyeti tarafından - kökeni batı dünyasına dayanan bir sistem olan - laiklik her ne kadar Fransa'dan alınmışsa da, Türkiye'nin kendi kültürel kodlarına göre olumlu ve/veya olumsuz dönüşümler ve/veya eklemlenmeler yapılarak uygulanan bir devlet sistemi halini almıştır. Dolayısıyla farklı toplumsal yapıların sayısınca farklı laiklik algısı ve sistemleri vardır diyebiliriz.

Günümüz Türkiye'sinde din-devlet ilişkisine ya da laikliğe ilişkin düşünce ve değerlendirmeler, siyasal ve düşünsel bölünmenin güçlü eksenlerinden birini oluşturmaya devam etmektedir. Ancak yapılan tartışmaların tarihsel temellerden kopuk soyutlamalar içinde gerçekleşmesi ve arkasında yer alan başka çatışmaları örtmeye hizmet etmesi, kavramların içinin boşaltılmasına ve tartışmaların altındaki zeminin tabir-i caizse erozyona uğramasına sebebiyet vermektedir. Bu nedenle bir kavramın ya da düşüncenin gerçekliğinin, işlerliğinin test edilebileceği en sağlam kriterin tarih olduğunu unutmamak gerekir. Tarih bugün olup bitenleri anlamamız için geniş bir perspektif sunar. Dolayısıyla yapılan yorumlar ve önerilen çözüm yolları, günümüz şartları göz önünde bulundurularak, kurumları tarihsel süreklilik içinde çözümlemeye dayandırılmalıdır. Din ve siyasetin de içinde yer aldığı kurumlar, kısa süre içinde değişmeyen, tarihsel birikimi bünyesinde barındıran oluşumlardır. Bu nedenle din-devlet ilişkisi veya laiklik konusu ele alınırken, tarihsel süreçteki düzenleme şekilleri, yaşanılanlar ve günümüz konuşlarıyla ilişkilendirilebilecek noktaları, bir diğer ifadeyle, tarihsel süreklilik ve değişimler dikkate alınmalıdır.

Mümtaz'er Türköne'nin Türkiye'de din-devlet ilişki modeli üzerine bir açıklaması konuyu özetler mahiyettedir:

“Türkiye'de resmen uygulanan 'din-devlet ilişkisi modeli' laik bir model değildir. Bu model, tarihi açıdan kendi içinde tutarlıdır; ama laiklikle ilgisi yoktur. Cumhuriyet Türkiye'sinin 'din-devlet ilişkisi modeli’ Emevilerde, Abbasilerde Selçuklularda ve son olarak Osmanlılarda uygulanan

\footnotetext{
12 Katolik Kilisesi'nin hakim olduğu Fransa'da, dinin kendi içindeki ve devletle olan çatışması son derece sert ve kanlı olmuştur. Özellikle Katolik-Protestan çatışmasının neden olduğu kanlı din savaşlarına son verme endişesi laikliği doğurmuştur. Kilisenin teşkilatlı ve nüfuzlu konumu, dini ve dünyevi iktidar arasında kolayca tanımlanan ve sınırları çizilebilen, ayrıştırılabilen bir mücadele alanı yaratmıştır. Arka planında "laisizm ve anti klerikalizm" bulunan Fransız modeli laiklik, kiliseyi siyasi ve iktisadi bir güç olmaktan çıkartarak, kolayca belirlenebilen din-devlet ayrımını uygulamayı mümkün kılmıştır. Ayrıca Fransız modeli laiklik için "laisizm" kavramını kullanabiliriz. Laisizm, laiklikten farklı olarak bir siyasi-hukuki prensip değil, bir ideolojidir.; Pozitivizm'in siyasal-hukuki-sosyal hayattaki yansımalarını ihtiva eder. Bu ideolojiye göre dinler müspet bilimin gelişmesi ve insan aklının bilinemeyenleri çözmesi ile tarihe gömülmüştür. Dinler; toplumsal, siyasal ve bireysel bir bütün alanlardan çıkartılacak, onun yerine insan aklına dayanan açıklama tarzları ve düzenler hakim olacaktır. Bu görüş, toplumsal ve siyasal olarak bir zorlayıcılığı, reddetme ve mahkum etme yoluyla dini alana müdahaleyi barındırır. Bkz. Mümtaz'er Türköne, "Siyaset", Lotus Yayınları, 4. Baskı: Ankara
} 


\section{Gül Tuba Dağcı, Adnan Dal}

modelin devamıdır. Din hizmetleri özerk kuruluşlara bırakılmamış, devlet teşkilatı bünyesine alınarak bir hiyerarşiye bağlanmıştır. Bu model, 14 asırlık Sünni geleneğini yansıtır. Tarih boyunca şeriat, kamu hukuku alanına sokulmamış, özel hukukun geniş bir alanı da siyasi iktidarın teşri faaliyetine konu edilmiştir. Her dönemde bir devlet dini, dinin resmi yorumu olagelmiştir." ${ }^{13}$ (Türköne, 2006)

Buna karşl1ık Niyazi Berkes de (bir nevi Türköne'nin düşüncesine bir ekleme yaparak) Türkiye Cumhuriyeti’nin Cumhuriyet ile laikliğe geçişini, (Kutsal) devlet bekası ile açıklar. Ona göre; "Devlet, din-devlet karışımının zorunlu olarak ayrılması sayesinde ayakta kalmış ve yok olmaktan kurtulmuştur. "14

Özetle, Batı'da laiklik, din ile ruhban sınıfının siyaset ve devlet yönetimindeki baskı ve otoritesini kaldıran bir yapı olarak doğmuştur ve kademeli olarak siyasi, sosyal, kültürel, ekonomik alanda gelişmiştir. Buna karşı1ık İslam ülkelerinde laiklik tedrici olarak gelişmemiştir; çünkü laiklik, İslam dünyasının kendi tarihsel, tecrübe ve kültür geleneğinin bir ürünü değildir ve aynı zamanda Avrupa ülkeleri tarafından uygulanan sömürgecilik politikaları çerçevesinde İslam dünyasında 19. yy.de ideolojik bir ürün olarak dışarıdan empoze edilmeye çalışlan bir oluşum olarak görülmüştür. Tüm bu etkenler İslam ülkelerinin kuruluş aşamalarında, laiklik mefhumuna ve sistemine tam olarak karşılık bulamamanın sıkıntısını yaşamıştır. Söz konusu bu sıkıntılar, laik sistemi tercih eden İslam ülkelerinde ciddi sorunlar ve tartışmaların oluşmasına zemin hazırlamıştır. Günümüz Türkiyesi'ndeki din-devlet-laiklik tartışmalarının süregelen bir çözümsüzlüğe dönüşmesinin temelindeki sebep budur diyebiliriz ki; günümüzde de hala Türkiye'de bu tartı̧̧malar devam etmektedir ve görünen o ki yönünün ve içeriğinin değişme olasılı̆̆ı var olsa da bu tartışmalar uzun bir süre daha devam edecektir.

\footnotetext{
${ }^{13}$ TÜRKÖNE, Mümtaz'er (2006), Siyaset, Lotus Yayınları, 4.Baskı, Ankara.
}

${ }^{14}$ BERKES, Niyazi (1984), Teokrasi ve Laiklik, Adam Yayınları, İstanbul 


\section{KAYNAKÇA}

BERKES, Niyazi (1978), Türkiye’de Çağdaşlaşma, Doğu-Batı Yayınları, İstanbul BERKES, Niyazi (1984), Teokrasi ve Laiklik, Adam Yayınları, İstanbul GENCER, Bedri (2000), “Türkiye'de Laikliğin Tarihi Dinamikleri”, Toplum ve Bilim, Sayı: 84, Bahar, ss 151171

MARDİN, Şerif (2012), Din ve İdeoloji, İletişim Yayınları, 21. Baskı, İstanbul

MERT, Nuray (1994), “Laiklik Tartışması ve Siyasal İslam”, Cogito, Sayı:1, Yaz, ss. 87-99

ÖKTEM, Niyazi (1994), “Dinler ve Laiklik”, Cogito, Say1:1, Yaz, ss. 31-47

TÜRKÖNE, Mümtaz’er (2006), Siyaset, Lotus Yayınları, 4.Bask1, Ankara

TÜRKÖNE, Mümtaz'er (2003), Siyasi İdeoloji Olarak İslamcılığın Doğuşu, Lotus Yayınevi, 3.Baskı, Ankara

İnternet Kaynakları:

ACAR, Sadık (bty), "Laiklik Konusunda Kavram Karmaşası", ss1-4

(http://kisi.deu.edu.tr/sadik.acar/dosyalar/LAIKLIK\%20KONUSUNDA\%20KAVRAM\%20KARMASASI.pdf) (e.t. 14.10.2014) 